$1-1-1957$

\title{
Behavior and Opinion Studies of Homemakers' Preferences for Hen Eggs
}

Norman Nybroten

Follow this and additional works at: https://researchrepository.wvu.edu/ wv_agricultural_and_forestry_experiment_station_bulletins

\section{Digital Commons Citation}

Nybroten, Norman, "Behavior and Opinion Studies of Homemakers' Preferences for Hen Eggs" (1957). West Virginia Agricultural and Forestry Experiment Station Bulletins. 400T.

https://researchrepository.wvu.edu/wv_agricultural_and_forestry_experiment_station_bulletins/640 @ WVU. It has been accepted for inclusion in West Virginia Agricultural and Forestry Experiment Station Bulletins by an authorized administrator of The Research Repository @ WVU. For more information, please contact ian.harmon@mail.wvu.edu. 
BULLETIN 400T

Hay 1957

IEHAVIOR AND OPINION STUDIES OF

Homemakers' Preferences

for Hen Eggs

ISST VIRGINIA UNIVERSITY AGRICULTURAL EXPERIMENT STATION 


\title{
THE AUTHOR
}

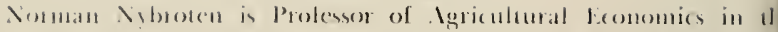

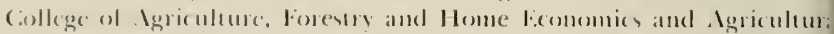

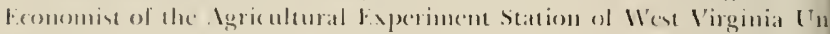
versis.

\section{ACKNOWLEDGEMENTS}

Ihe data for the several studien reponted in this bulletin were a

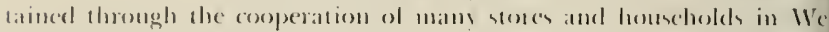

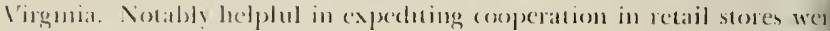

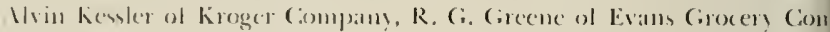

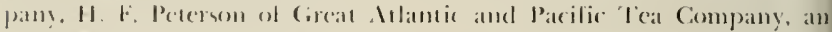

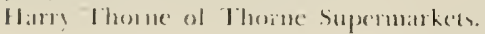

Dlthemglo interpretations are solels the responsibility of the autho

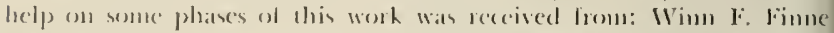

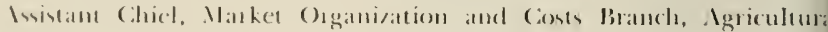
larketing Service, United States Deparment of Igriouluure; Romal

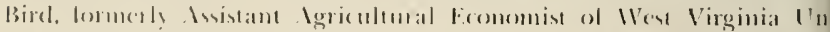

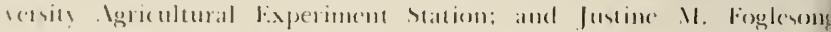

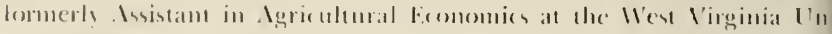
versity Igriculumal Experiment station.

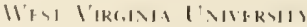

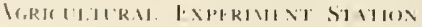

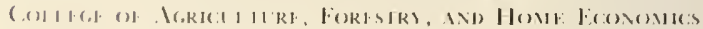 \\ H. R. VIRNIY, DIRIC,IOK \\ ILOKG.NIOINT
}




\section{Summary}

The reseath on which this report is based was dome tumeler several

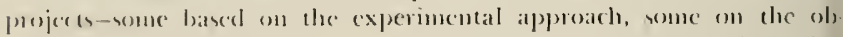

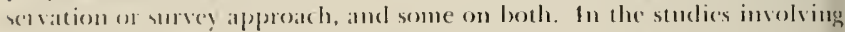

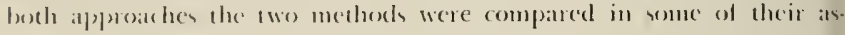
perts.

Inalises of the ditat received from the two approathes indicate that

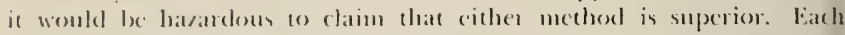
methose seems (1) have its place, depending on the objectives of the reseasch and the nature of the preference or acceptance being studied. II the prefereme xems to be of litte immediate comomic importance, and il the destinction diflerentiating the products or services is a simple

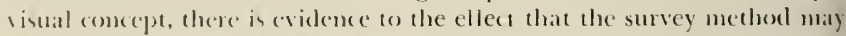
bring alsont more serions comsmoner consideration more readily than a alesigned matched-lot experiment. Isolating the variable is a problem in both mechosls, but perhaps mose dillicult in the experingental method

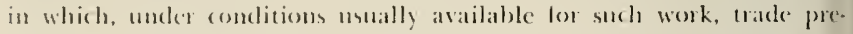
judices temd to become comboumded with the intmoluced vatriables.

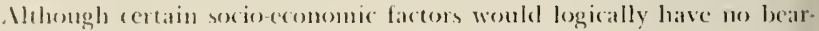
ing on the prederence or acceptance at issue, they may be of impontance in analysis. Some of these latoos shomld be used in sample and analysis statilication. Thes also become important in weporting resules in a

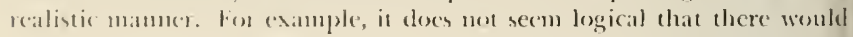
le at sgmificant relationship between preference for shell rolor of egg and the amome of formal education received by the person whose prefcrence is being studied. There is, howerer, an association, and regatrdless

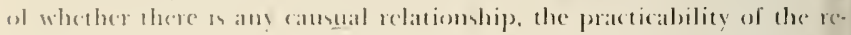

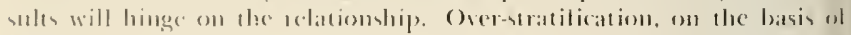

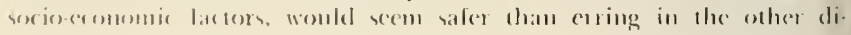
rentirsl. 
(he basis lor this report. Ml hough the work pertaims to egge, some gener. al shoppling opmonoms and practices which might have bearing an the problem or the results were sudied and ane being presented.

\section{Importance of Eggs in Choosing a Retail Store in Which to Shop}

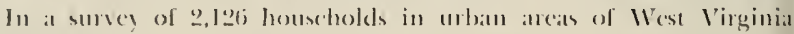
the homemaker, of the nearent atrailable substitute at the time of the intervicw, was asked, "If you yplit yout sloppring among sereral stores,

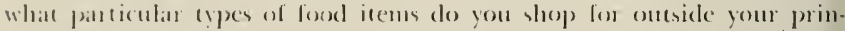

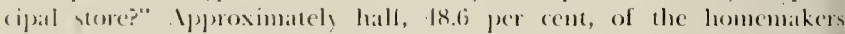
statted that they split their shoppoing antong stores or other someces. This varied signilacantly by income ancea in which the household wats bocaled (sece lable 1). When this guestion was put to the intervewee there had

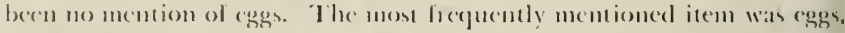

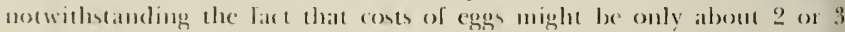

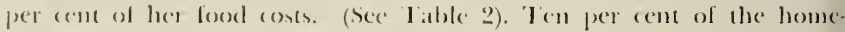

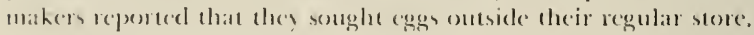

The relatively large ummlen ol homenakers who stated that they

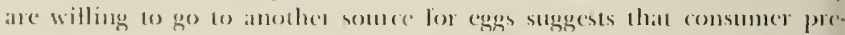
ference studies on egges at the retatil level might be both practical and

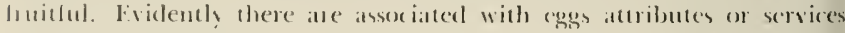

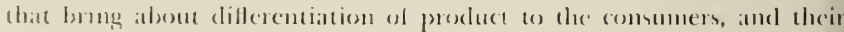
dillerentiation as a whole is of coomomic importance. The late that shoppers will go to a different store to seck llese services and attributen indicates that these is enough sensitivity in the dematnd to promise some results from preference sudies, live lactors need to be determined(1) what the important attributes or services ate, and (2) the ecomomics ol matering in terms of these attrilsutes.

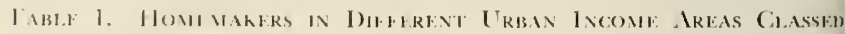

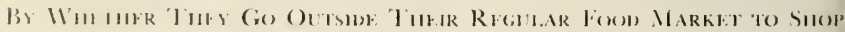

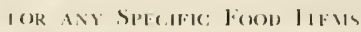

\begin{tabular}{|c|c|c|c|c|c|c|}
\hline 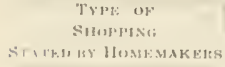 & $\begin{array}{r}\text { [a] } \\
\text { [xcom }\end{array}$ & $\begin{array}{l}\text { ANI } \\
\text { AREAS }\end{array}$ & \multicolumn{2}{|c|}{ 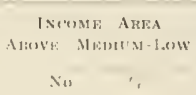 } & \multicolumn{2}{|c|}{$\begin{array}{l}\text { ALL, } \\
\text { INCOME: } \\
\text { ALEAS }\end{array}$} \\
\hline 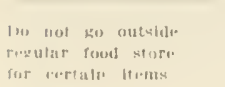 & $35: 5$ & ix 2 & Nu & ' & 10192 & 51. 1 \\
\hline $\begin{array}{l}\text { (in out ide regutaty } \\
\text { foot store for } \\
\text { artain limu }\end{array}$ & 25.14 & 41.s & 780 & 51.3 & 10.34 & $4 K . f_{i}$ \\
\hline To1:11 & $1 ; 17$ & & $151: 4$ & & 2126 & \\
\hline
\end{tabular}

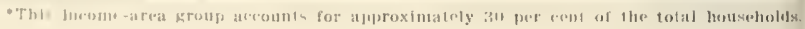




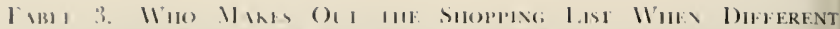

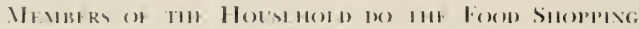

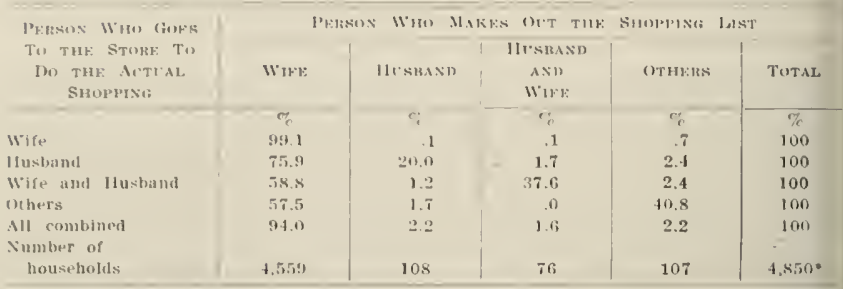

-Thirty-one respondents staled that they never usod shopulng lists.

did the food shopping in 81.8 per cent of the households. (See 1 able -1). This, of course, may lo quite dillerent for rural houscholds. II the husband and wife made ont the shopping list together. the odds were about "2 to I that if only one would go to the store, it would be the huslsand: howerer, 8. per cout of the time they both wene in this case.

Ilthough the wile mstally makes out the shoppoing list and also does the shopping. it dex not follow that she shope on the basis of hes personal preforences. This also tends to be the arse for other mem. bers of the lowschold when they shop for ford. 'The aliflerent ford litstes of a lamily must usually be comsidered by ahe person who makes the foud derisions lor the limily.

\section{Comparisons of Survey and Survey Results with Experimental Results}

\section{ICGC; C.IRTONS}

I matched-lot experiments was 1 mo in a retail store to determine the

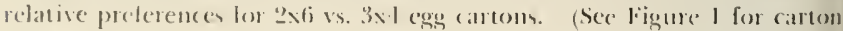
(vpens.)

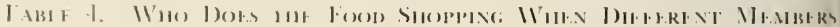

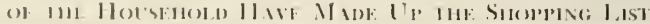

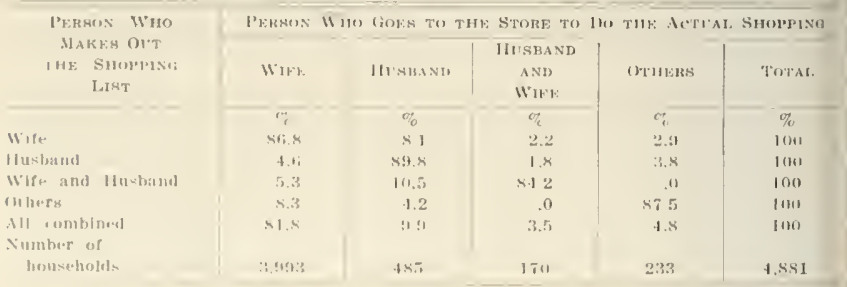




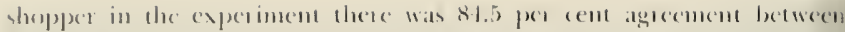

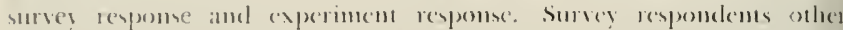

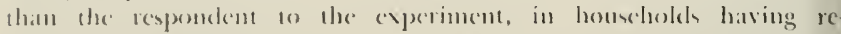
ecived pumbanes lom the experiment, howed virtually the same agree mant between surte and experiment response as surver respondents wh

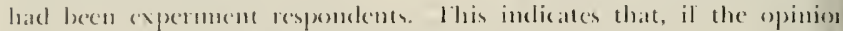
leals with a simple, (mmmomplace, visnal concept, the opinion of am adult momber ol the bouselubl likely to be lomol heme is probalsly at

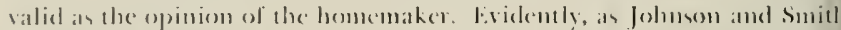
anserted, a sures does nost "exclude from comsideration all who inllueno

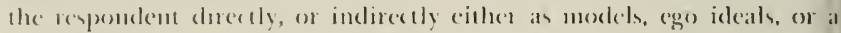

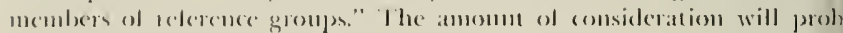
abl! vaty with the nature of the guery.

()ne () the achlting probleme in analysis is that of classilication simple (limses of only respendents, rather than of lactors in the reles

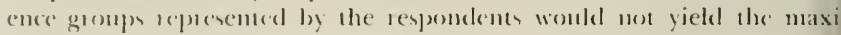
mum amoum of inlommation inherent in the ditti. Multiple cros classilicatums between repondents, relerence groups, and the variabl uscler studs would be reguired. This would be true for both surve datat and data lom comtrolled experiments.

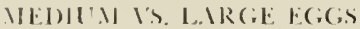

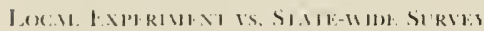

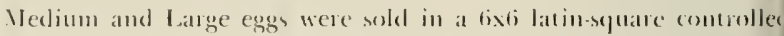
experinctu in the dominant retail store in onc smatl city. In this ex

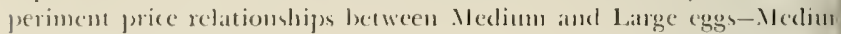

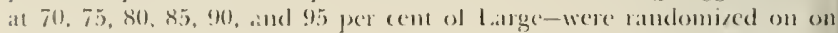
orelinate and the six days of the week on the ofher ordinate. This re sulfed in daty changes of the price relatiomship between the two size: I o saleguand against latkage of inlomation which might canse shoppes

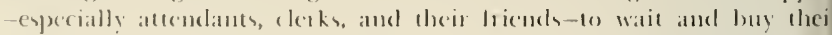

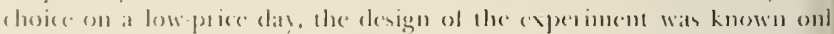

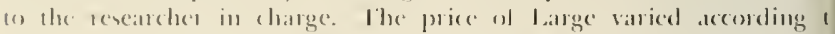

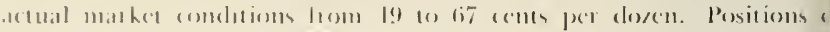
Medimm and lathe in the displas were interelatmged twice daily. I thongh this was a stidat design, the experinent was rut six extra day

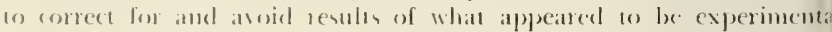

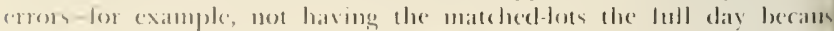

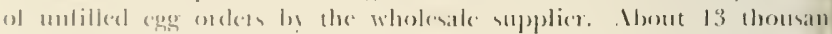

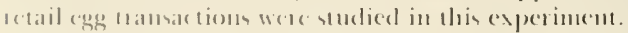

Resules ol this expentment are smmmatred in the bat (hate show

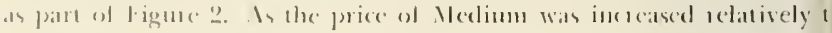

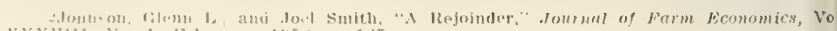

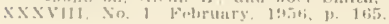




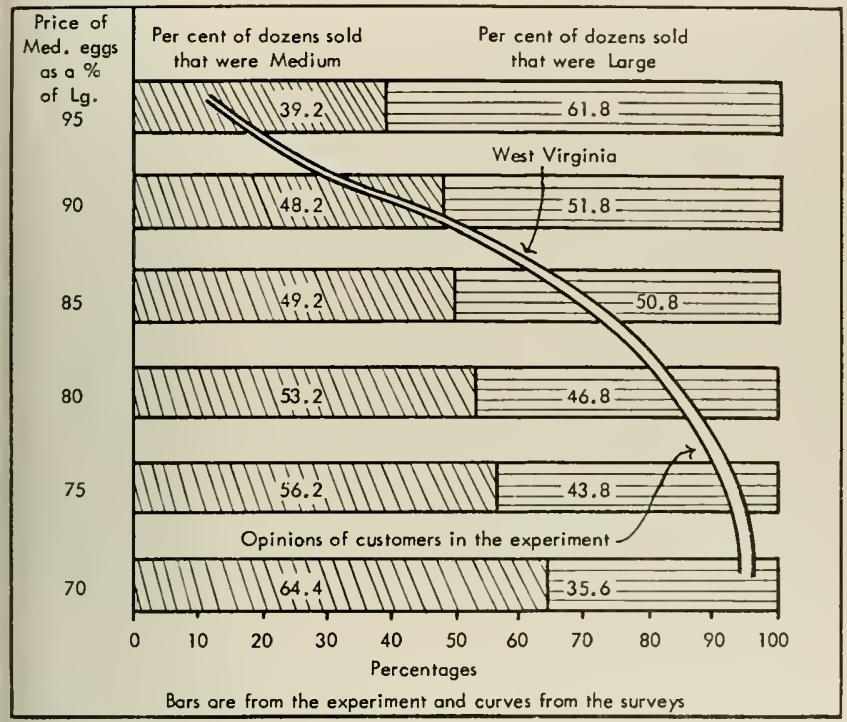

FIGURE 2. Percentages of total dozens of eggs experimentally sold represented by Medium and Large eggs and percentage of respondents to a survey who would buy Medium eggs under six different relationships between the prices of Medium and Large eggs.

the price of I arge there was a definite decrease in the salen of Medium relative to the sales of Large. With the price of Medium at 70 per cent of the price of lange, just under two-thinds (6it.t per cent) of the dor. cms wal wore Medium. With the price of Medium at 95 jer cent of Large, the . Iediums accomted lot 39.2 per cent of the domens sold.

Yedimm eggs, with a minimum perelosen weight repuirenent of 21

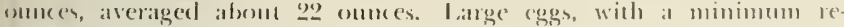

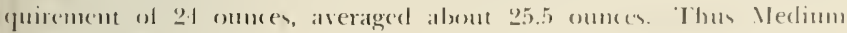

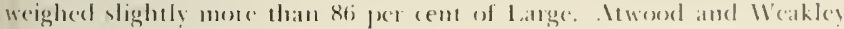
fommet that the latio ol wolk tor egg white is slights higher in smatlet

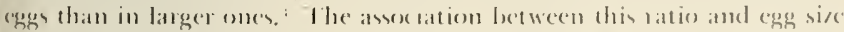
is se low, howerer, that the mutritional values ol egge of dillerent weights are practically in direct straight-linc redation to the weight. From this it follows that the motritional value of the Medium egg would be alom sef

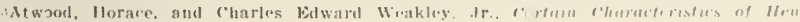

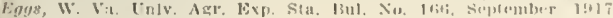




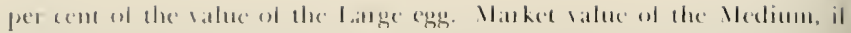

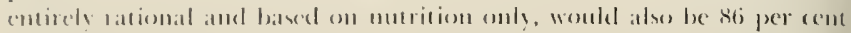
al the Litrge:

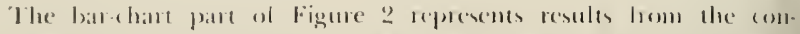
wolled retail experiment, whereas the agive curves represemt compantable

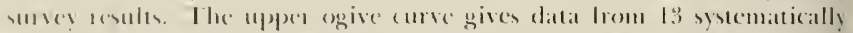
seleded unban alleas of 11 end Virginia. Willin these areas 1,572 interbews were mate in houseluskls selected at randem. In the store experiment the price of latrge ranged from is to 67 cents per closem. In the

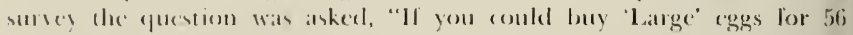

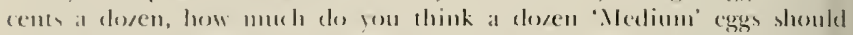

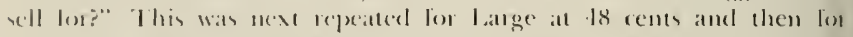

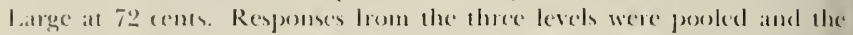

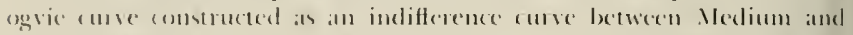
l.ange. Note that the stare! results were in the same direction as the experinent resule, but lluere was a great dillerence between the two types

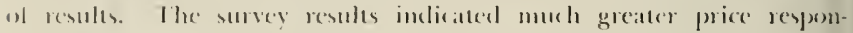
sireness that the experintent results. On the basis of mutitional value, the respentemes ophomions of values were more rational than were the

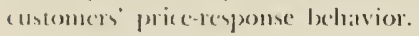

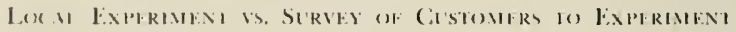

ln the retail experinent on Medium is. Latrge eggs the mane, adelress of the purchaser, what wats purdhased, and under what matchedelot choice, were recoreled lor each purchasc. In all, alsoul 5,500 enstomers

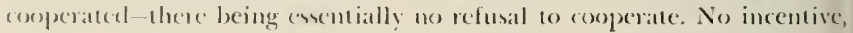
other than explatumg the researeh objetives and that the thiversity was conducting the experiment, wats tused to obtain this comperation. Customers smmetimes objected to giving theil manes more than onte, but a very short explanation vintablly always brought lull cosperation.

I simple of the castomers as the experintent was setected to become patt ol the state-wide smey and at the some time lumish data for

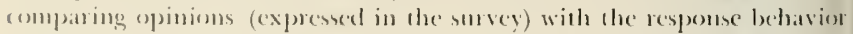

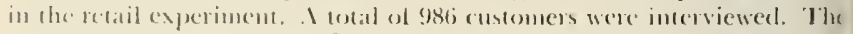

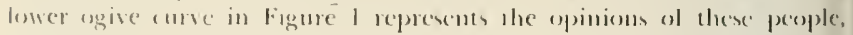

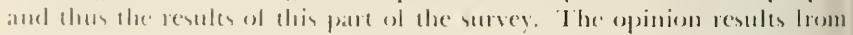

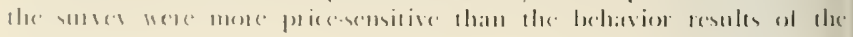

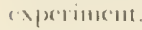

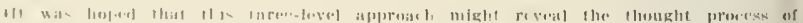

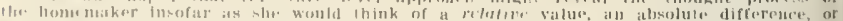

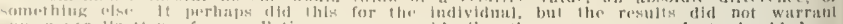

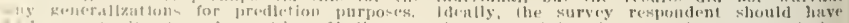

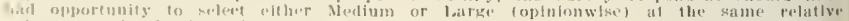

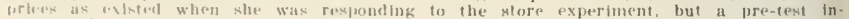

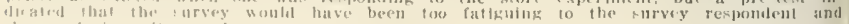

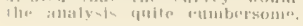


Because this store had hitherto put vely little emplosis on marketing Medium eggs, it secmed that the Large egg would have a built-up advantage, compared with stores having given more equal emphasis to the two sizes. The indillerence curve for customes to the experiment is about the same as that for the pooled areas, indicating about the same cross clasticity for Medium and Large eggs. Whether the experiment fairly represents what would have happened in a state-wide experiment has not been detemined, but the similarity of the wo indiffrence curves tcude to support the inference that the urban area chosen for the experimene might represent the urban areas of the State. If there had been a closer relationship between opinion and behavior, grater credence could have been given to this inference.

- Ipporoximately $\$ 6,000$ more net income could be eaned in the retail store in which the experiment was performed by handling Medium eggs, granted the following hypotheses: (a) no effect on store's total (ggg volume from handling Medium; (b) no effect on wholesile prices of eggs; (c) expense of handling a doren Medium eggs the same as handling a domen Large: (d) no extra costs due to handling two dasses of eggs rather than only one: (c) and that the experiment is representative of what would happen in the long rum in the store. Because some of of the customers definitely sought Medium egge it is probable that the whume ol sales of eggs was increased by ollering the Medium egg along with the Large. The nee income from this pobably more than offset any extra costs of handling the additional egg size. Acmally, the volume of egg sales did increase while Medium eggs wore being offered, but the controls or checks in the experiment were inaleguate to determine whether the increase was due to the extrat ollering on to some other cause.

\section{SHILI, COOLOOR OJ FE,GSS}

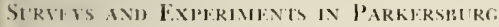

Parkershurg, West Virginia, population about fo, (0)00, was included as part of two state-wide surveys ol homemakers opinions on egg shell

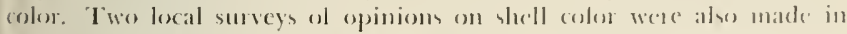
Pankershorg. Althomgh there is a comsiderable dillerence in the resules

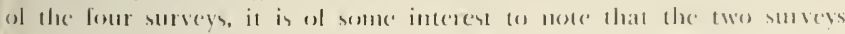

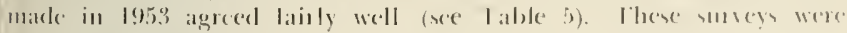

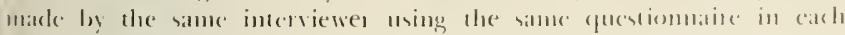

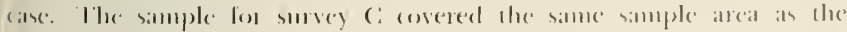

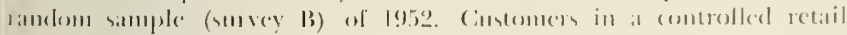

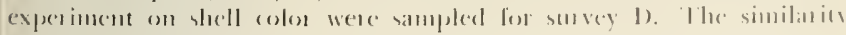

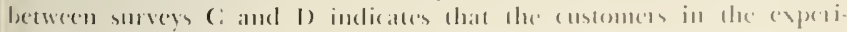

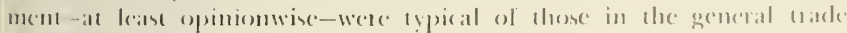
area. 


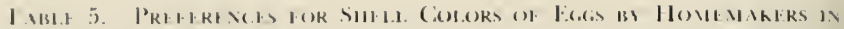

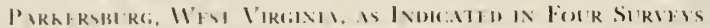

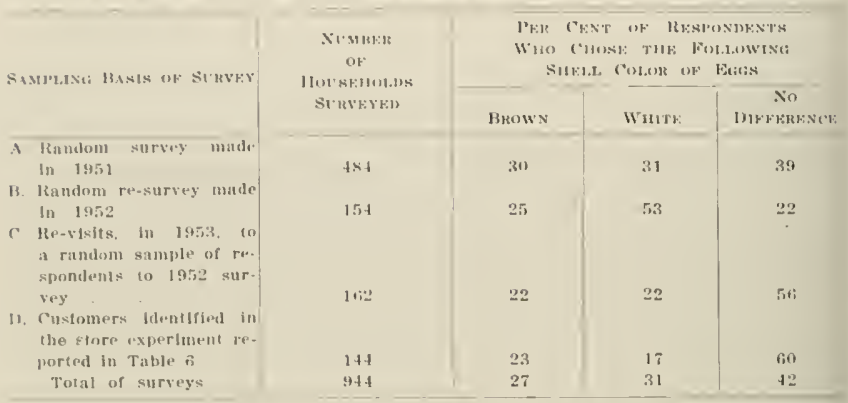

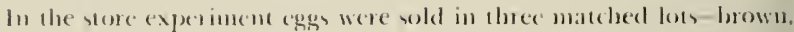
whice, atsel mixcel. Relative posttums of the these lots were randemised twice dats amel sales imentorien, taken lor cach change ol position. "The experiment was 1010 lor cight weeks with brown and white alway priced alike, and the lirst low weeks mixed colors, poiced the same as the

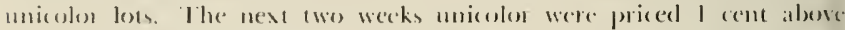
mixcel, and the hast ewe weeks mincolon were priced 2 conts abose mixed.

Resules ol the experiment ane stmmarised in lable b. It there hat been a perlect (1)telation between (p)

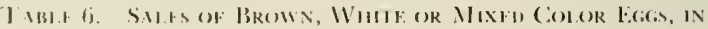

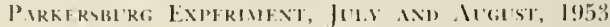

\begin{tabular}{|c|c|c|c|c|}
\hline 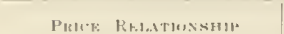 & Patentate & Tutal Hatis Sut.D & THAT & Wи:ки: \\
\hline ค & BHoWN & WHiTk & & M1X:1) \\
\hline All three lote same. & 34.3 & 11.2 & & $2+.5$ \\
\hline $\begin{array}{l}\text { Hotb hrown amb whit ont. } \\
\text { chell above mixed }\end{array}$ & $24+$ & $3 f i .4$ & & 34.2 \\
\hline 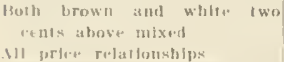 & $\begin{array}{l}34.5 \\
32.4\end{array}$ & $\begin{array}{l}35.8 \\
34,2\end{array}$ & & $\begin{array}{l}3.7 .7 \\
198.4\end{array}$ \\
\hline
\end{tabular}

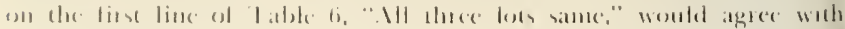

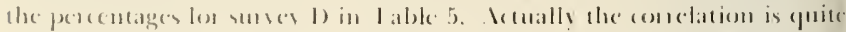

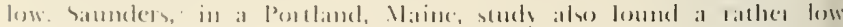

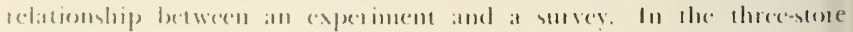

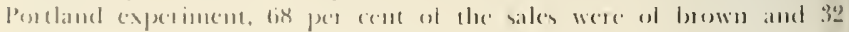

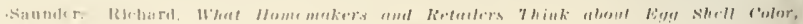
Matm. Ier Exp, Eta BuI No. 


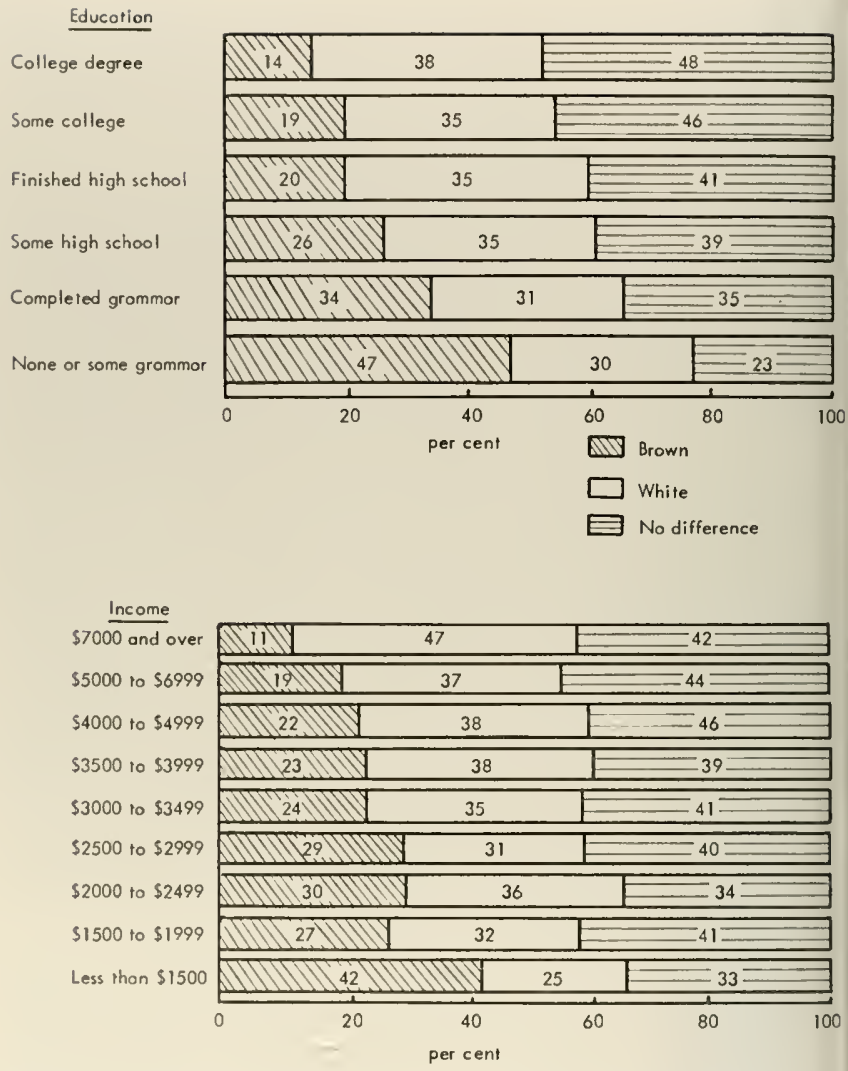

FIGURE 3. Preferences for shell color of eggs by homemakers of various levels of education and family income-West Virginia cities, 1951.

stategs were mate in 1953, in which was asked, "Whate color exges dos

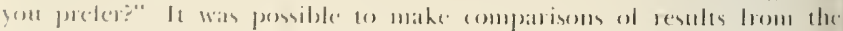

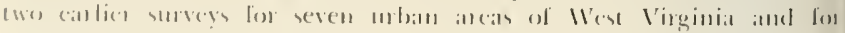

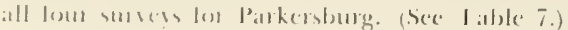

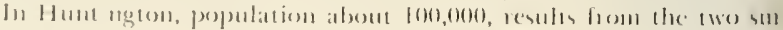

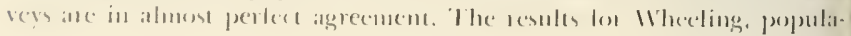




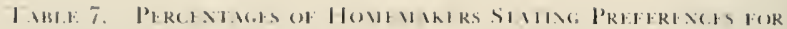

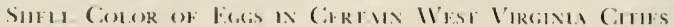

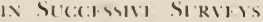

\begin{tabular}{|c|c|c|c|c|}
\hline $\begin{array}{l}\text { Ciry AND } \\
\text { Strvex }\end{array}$ & 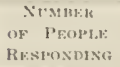 & $\begin{array}{l}\text { PEER CENT OF } \\
\text { WHITE }\end{array}$ & $\begin{array}{c}\text { ReAlonimexta STATING } \\
\text { BHWWN }\end{array}$ & 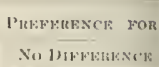 \\
\hline \multicolumn{5}{|l|}{ limkley } \\
\hline $\mid\{15 \mid$ & $27: 3$ & 45 & 19 & in \\
\hline 1952 & 149 & 43 & 21 & 31 \\
\hline \multicolumn{5}{|l|}{ Clarkshurg } \\
\hline $1: 051$ & 521 & 30 & 35 & 35 \\
\hline $19.52=$ & 310 & $\therefore 2$ & II & 27. \\
\hline \multicolumn{5}{|l|}{ IInutiugton } \\
\hline 1951 & 5019 & 42 & 25 & 3.3 \\
\hline 1952 & 259 & 13 & 24 & 33 \\
\hline \multicolumn{5}{|l|}{ Martinsburk } \\
\hline 1951 & 135 & Is & 52 & 30 \\
\hline 19152 & 1511 & 11 & 31 & 58 \\
\hline \multicolumn{5}{|l|}{ parke-saburg } \\
\hline $195 !$ & tist & $: 1$ & 30 & 39 \\
\hline $155: 3$ & 154 & $5::$ & 25 & 22 \\
\hline $1: 15: 1 \bullet$ & 162 & 22 & $\because 2$ & 56 \\
\hline $145: 3$ & 141 & $3 x$ & 17 & 60 \\
\hline \multicolumn{5}{|l|}{ Nestun } \\
\hline 19.51 & 531 & $3+$ & $\therefore$ :ai & 30 \\
\hline $1: 152$ & $5 \%$ & (i) & 111 & 20 \\
\hline \multicolumn{5}{|l|}{ Whxpling } \\
\hline 1051 & .201! & $a$ & 15 & 49 \\
\hline 1952 & $24 k$ & 52 & 26 & 22 \\
\hline
\end{tabular}

-Thts was the same simple area as that used for the 1952 survey

This was a samplt of customers who bought eggs in al controlled reatil experlum ronductert in 19.73 .

Indications from the starveys ate that the preferene len shell colo of eges is, fos the great majorits ol people, only of a very mild anture

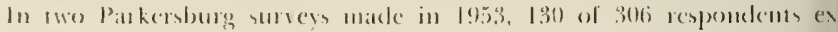

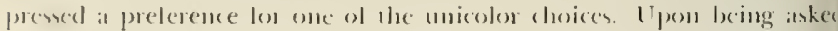

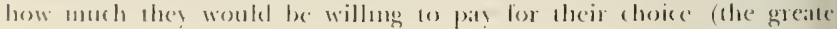

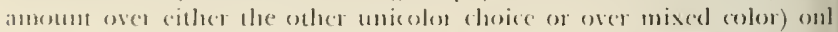

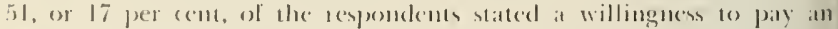

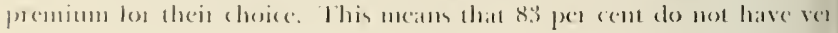

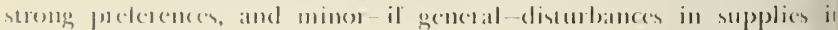

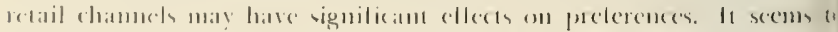

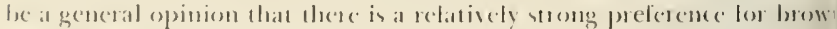

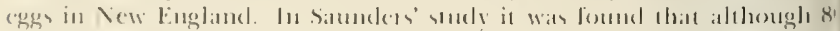

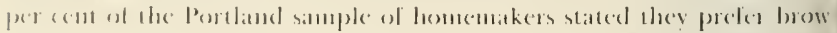

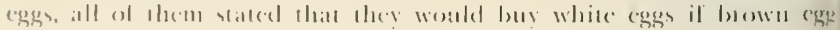

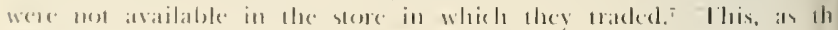

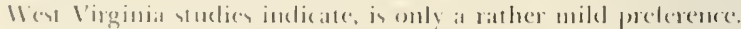

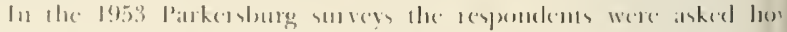

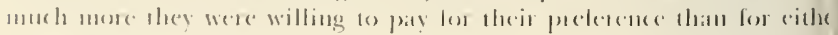

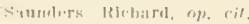


al respondente making choses att dillerent lesels of ratios. There was a ditcet iclatiombhip between the dillerences ol the standand deviations and the pencentage ol respondents who chose the more anilome cggs. "Jhere was no definite "Ineaking poime" at which there was a preponderant shile un the mose mollorm.

Respondents were asked to give the reason lor their choses. Al though the regression was sigmalicant, Aheis reasoms were relativels illogical and imsignilieant as a whole. It secmos that there must have

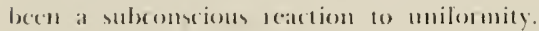

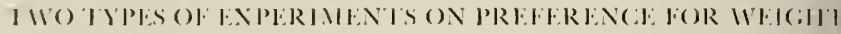

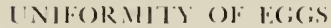 \\ l:Xr. RIMLNI I}

I matched-lot retail store experiment was designed in which in dividual cggs ol dilferemt sires within the dosen were ollered lor sile The sariation ol egg siges within the dosen was controlled in a man ner that the most milemmly-sised lots were more miform than coule

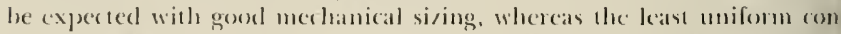
taincel comsiderably mone variation than was fomel in nest-rust eggs.

In oreles to contesl the vasitions withis the dosen, a rather pre

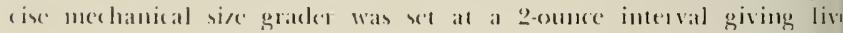

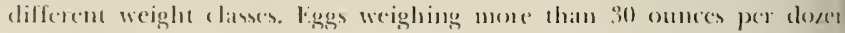

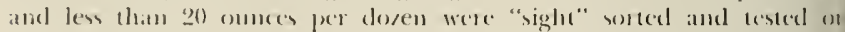
hatul scales and rejected lom the experinente Doing this "sight" ane "hand" work was not an terlious as might be cxpected berature thes were lace exteme dasses with relatively lew eggs.

lable ! show the sising limis, unced in sorting the live dilferen weight rlasses ame the average weight uscel for variance calculation The midlpoint ol cach weight class taken oll lle siec (actually weight

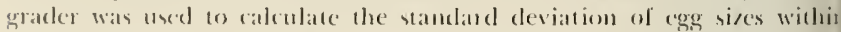
the descollate is, all eggs in a weight class were assmomed to have th merlian weight ol the tass. For cample, the eggs lalling into the lire

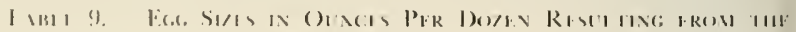

\begin{tabular}{|c|c|c|}
\hline LAWER LAMT" & I'Prkk LAsur* & 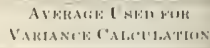 \\
\hline 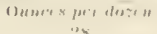 & (1)nners pure tln:an & (moness prov Hoxe" \\
\hline $2 x$ & $:: 11$ & 29 \\
\hline $24 i$ & $2 x$ & 27 \\
\hline 21 & $24 ;$ & 25 \\
\hline 22 & 24 & $2: 3$ \\
\hline 2011 & 22 & 21 \\
\hline
\end{tabular}

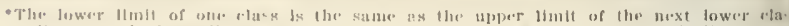

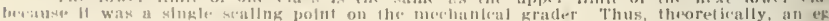

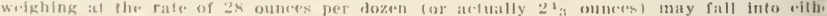

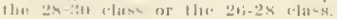


I his grompmg of the sameland eteviatioms mate it possible to som

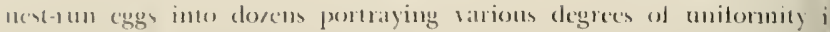
the doren. Fin instance, in (isoup I there would be very miforml sired eggs and in (iroup It' there weuld be eggs showing more vari: lion than would be expected in nest-rum eggs.

In order to determine what sests could be used most atvantage

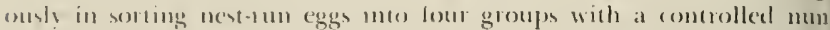
lxer ol eggs in rath grompe, a case of cegs was sorted into the live it diviclual sise chameds as mentionted previously. I comme of the numbe of eggs in each daanmel was taken and then the sorts mecessary to ol

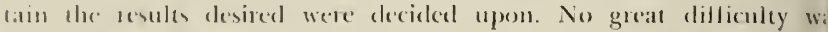
(oncontered in selenting standand deviations os lit the specilieation (s) the lour gromp. Il the socllicient ol variation, rather than standan deriation, hat bern the eriteriom, the prosedure would have becon me mence dillicult. Ocrasionally in soming the los for the tay a lew rege were lelt were in cach groups and thus alid not become part of th ('xperiment.

Fach dar the doren price ol eggs was set by the retailer. I'h price was then comserted to a companable price by weighte. Each doze of eggs was then weighed and the weight and price of the carton , cgigs was stamped on it.

A tlisplay sign was shown above the eggs stating "Grade $A$ egg

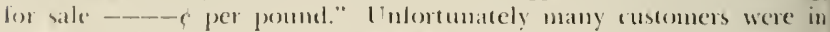
pressed onty by the late that eggs were heing sold by the pound and pai no attention (o) the variations in size.

The low differeme size groupings of eggs were displayed mattede lot an a talule in distimely separate gromp with awo catcons in cas grenty open for the inspection of the shopper. Al all times ther was an attembant available to answer yuestions pertatimg on the qua ity of the egge and why they were being sold in that mamer. Th attendime also wote down emments mate by customers. The grote were enated in their elisplay poition on the table several times du ing the daty. In equal mumber of egges was kept in each group. In

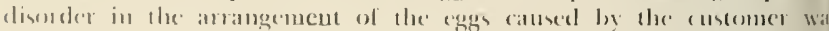

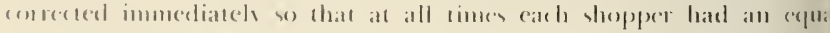

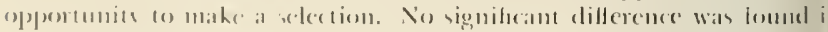

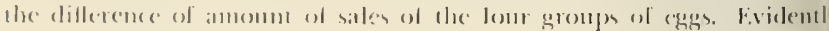

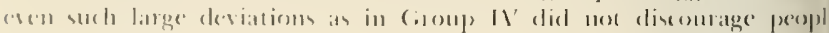
trom lnusing.

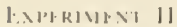

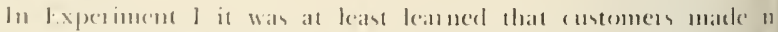

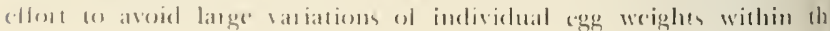

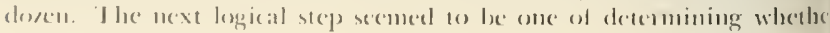




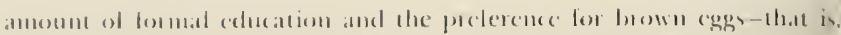

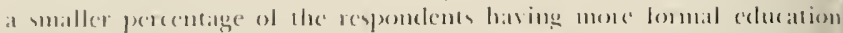

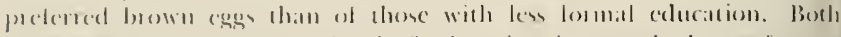
survers showed thate as the level of education increased, the pucterence

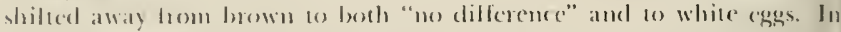

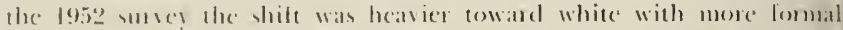
education. Reasons lor this type of shile with education ane speculative, but it is doublat that perople hate been tatught to wame white rather

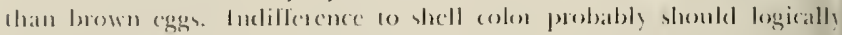
imescase with the ameune of lommal colucatum, lout this should be

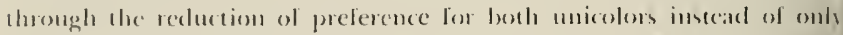

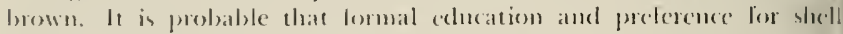

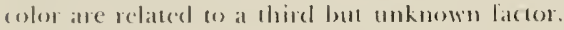

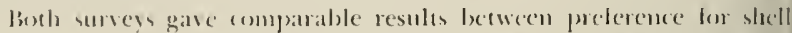
colen and income of the responding fanily. As incomes increatse, the preforence Tor white egge increases and does so vintually (ntirely at the expense of brown.

Bosth celucation and income were alternately held comstant te:

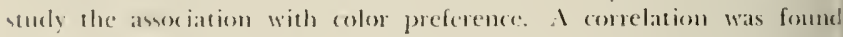
betwern income and edustion, and the principal reason for the relation beween income and preference was this corrctation plus the correlation between celusation and preference.

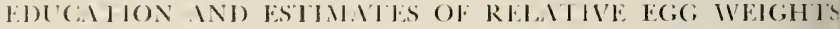

In the state-wide survey respondents were told that Medimm egg

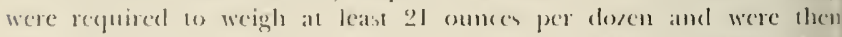
asked how much they thought a doren lange egge must weigh. The replies were classilied loy the amoum of formal celucation of the respond (nit. It was foumbl that reluctance to cotimate varied disectly with the amounc of formal celucation.

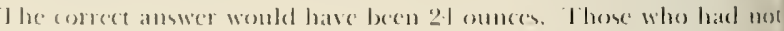

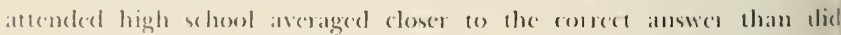
ihose who hatel a greater amomm of fommal celucariom (see lable ll)

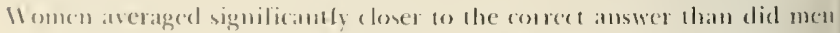

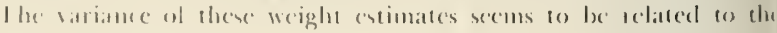

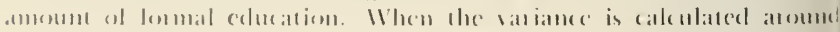

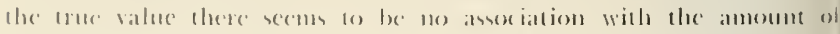

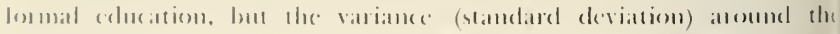

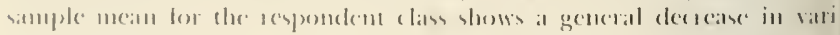

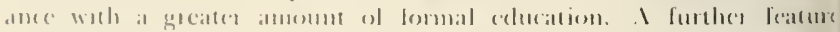

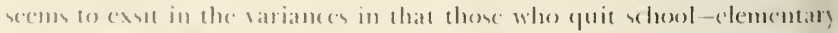
high, of college-hate a galeater san iance ol estimates than clid those whe compleced these livels ol schooling. 


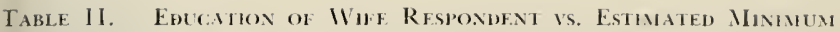
WFight RFQUIRFMFNT OF LARGF. AS COMPARED WITH THE RFQIIRED WEIGHI OH: DI OINCFE FOR MIFIJII

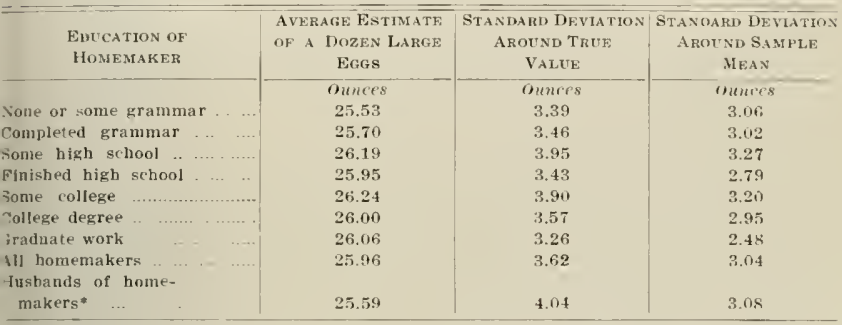

"These were not the husbands of "All homemakers" but were rather husbands of comemakers not available for tnterview.

\section{EDUCITION AND ESTIMATES OF RELATIVE}

\section{ALUES OF MIDJUM AND LARGE EGGS}

Despite the fact that those with a greater amomnt of formal educa. ion did a poorer job of estimating the relative weights of eggs, their stimates of relative zalues of Medium and Large eggs were better than hose of people with less formal education. Table I2 show's that a langer rercentage of those with more education were essentially corred in heir estimates. Those with more education tended to over-estimate the alue of Mediun, whereas those with less education tended (o) undervimate Medium.

\section{NCOME AND ECONOMY AS MOTIVATION}

Upon being asked why they chose eggs of a certain weight class, a reat majority of the people indicated that they did not try to be

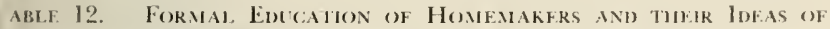

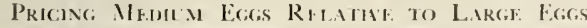

\begin{tabular}{|c|c|c|c|c|}
\hline \multirow{2}{*}{$\begin{array}{l}\text { IMUT'NT HF HOHMAL, } \\
\text { BDTCATHN OF THF: } \\
\text { HOMEMAKRK } \\
\text { RESPONDENT }\end{array}$} & \multicolumn{4}{|c|}{ 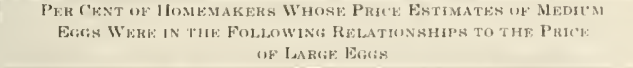 } \\
\hline & 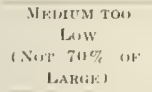 & 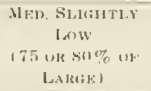 & 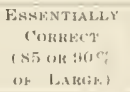 & 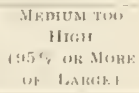 \\
\hline 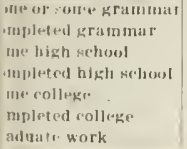 & $\begin{array}{l}1401 \\
4.1 \\
6,2 \\
3.8 \\
21.3 \\
2.1 \\
1.5\end{array}$ & $\begin{array}{r}18.3 \\
17.11 \\
16.3 \\
13.8 \\
11.4 \\
19.2 \\
8.8\end{array}$ & $\begin{array}{l}19.7 \\
53.2 \\
52.9 \\
575 \\
112.2 \\
1.4 .8 \\
1,4.0\end{array}$ & $\begin{array}{l}17.11 \\
\because 17 \\
21.15 \\
21.91 \\
23.1 \\
2 \because .91 \\
25.7\end{array}$ \\
\hline
\end{tabular}


eomomtcisl in then tecision as to what agg size they would but (see Iable I:3). (Only alout one-sixth of the homemaker indiented that they

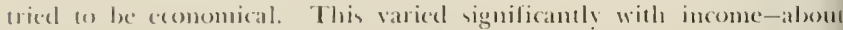
2(1) per ecut ol those with less than \$3,000 family income ammually and

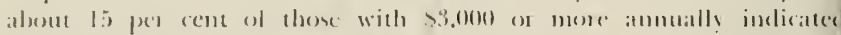

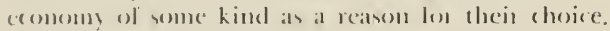

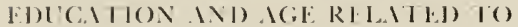

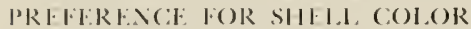

ls womlel be expected lom the trend toward more lomal education

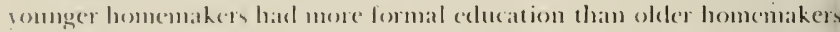

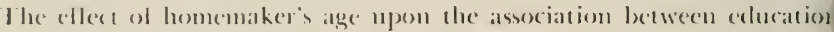
and color preference was investigated. The resules ol this are slowe in Iialse 11.

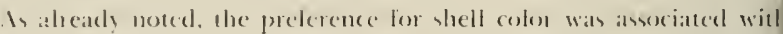
education. It evidemty was not associated with the age of the respondent

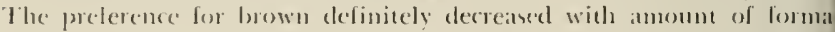

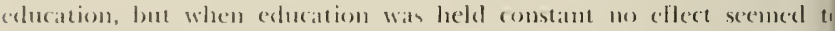

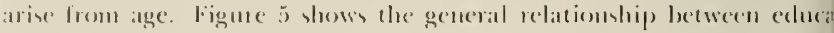
tion ambl shellecolor prelesence.

\section{Amount of Eggs Used by Household Affected Relative Valuation of Medium and Large Eggs}

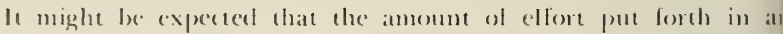
economis valuation would be diretly related to the exomomic impon

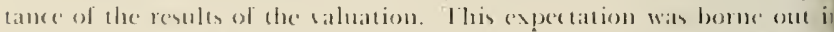
studyiug juelgunents ol relatise values of Medium and Latrge eggs. I The n sulting values, based on purchases in a matchedfot experiment, wer definitely asseriated with the number of dosen used per week by th homscholel (see 1 able 15).

Is a 1 ule the mone agge a household med the more likely it was t

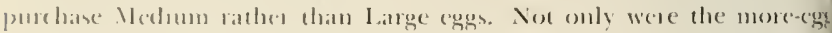

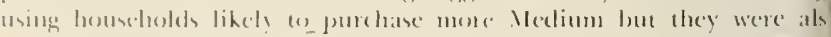

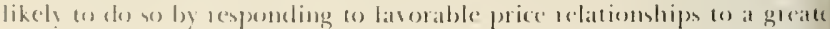

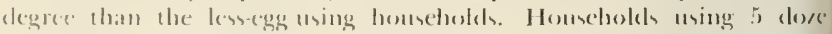

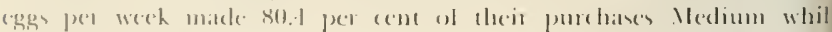

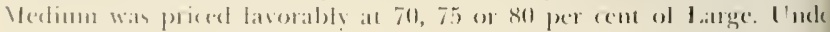

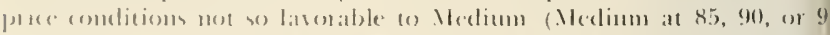

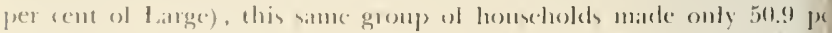

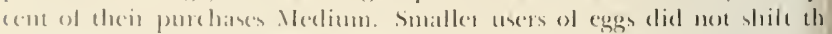

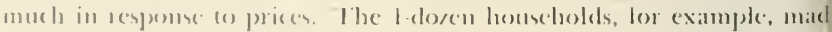

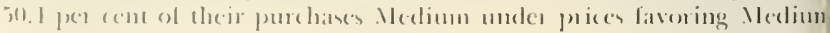


ABLE 13. ECONOMIC REASONS COMPARFI) WTTH OTHER REASONS FOK Choosing Eggs of a Certain Weight Class Statfo bi Hovesakfrs in Two Family Classes in West Virginia Cities in [95]

\begin{tabular}{|c|c|c|c|}
\hline $\begin{array}{c}\text { IXCOME OF } \\
\text { THE } \\
\text { FAMILY }\end{array}$ & $\begin{array}{c}\text { NeMBER } \\
\text { OF } \\
\text { HOI'SEHHLAS }\end{array}$ & $\begin{array}{c}\text { ECONOMIC REASONS, } \\
\text { SI,H AS CHEAPER } \\
\text { OR BETTER HA'Y }\end{array}$ & $\begin{array}{l}\text { OTHER FEAXUNS. } \\
\text { SICH AS HABIT, } \\
\text { AYAILABLK. ETL. }\end{array}$ \\
\hline ses than $\$ 3,000$. & 1,697 & 19.7 & $\begin{array}{c}\% \\
80.2\end{array}$ \\
\hline s.(nn) or more ..... & $2.4+52$ & 15.4 & $8+f$ \\
\hline Total & 3.749 & 17.4 & 82.6 \\
\hline
\end{tabular}

ABI. 1-1. AGE AND FORNAL EDTCATION OF HOMENAKERS AND STATED Preferences for Shei.1. Color of Egg.s, West Virginia, 1951

\begin{tabular}{|c|c|c|c|c|c|c|}
\hline \multirow{2}{*}{ 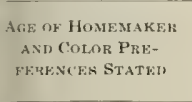 } & \multicolumn{6}{|c|}{ AMOUNT OF FonMal, EDICATION } \\
\hline & $\begin{array}{l}\text { NONE OK } \\
\text { SOME } \\
\text { GRAMNAK }\end{array}$ & $\begin{array}{l}\text { COMPLFTED } \\
\text { GRAMMAR }\end{array}$ & $\begin{array}{l}\text { SOME } \\
\text { HIGH } \\
\text { SrHOOL }\end{array}$ & $\begin{array}{l}\text { ('OMPLFTEA) } \\
\text { HJAH } \\
\text { SCHOOL }\end{array}$ & \begin{tabular}{|} 
SOME \\
COLLFGE
\end{tabular} & $\begin{array}{l}\text { COLLEGE } \\
\text { DEGREF } \\
\text { \&.UORE }\end{array}$ \\
\hline or less & $\% *$ & ;o & $\%$ & s & $\%$ & $\%$ \\
\hline White & $\mathrm{x}$ & 25 & 37 & 39 & 39 & 36 \\
\hline Brown $\quad \ldots . . . . . .$. & $\mathrm{x}$ & 45 & 21 & 20 & 14 & 14 \\
\hline $\begin{array}{l}\text { No difference ...... } \\
\text { to to }\end{array}$ & $\mathrm{x}$ & 30 & 42 & +1 & 47 & 50 \\
\hline White . & 36 & 33 & 38 & 43 & 35 & 32 \\
\hline Hrown & 44 & 36 & 30 & 18 & 18 & 15 \\
\hline $\begin{array}{l}\text { Xo differeme } \\
10 \text { 5il }\end{array}$ & 20 & 31 & 32 & 39 & 47 & 5:. \\
\hline White & 35 & 34 & $3: 3$ & 34 & $: 12$ & as \\
\hline Brown & 42 & 33 & 25 & 24 & 19 & 14 \\
\hline $\begin{array}{l}\text { No ditference } \\
\text { to } f(1)\end{array}$ & 22 & 33 & 42 & +2 & 49 & 18 \\
\hline White . ... & 21 & 29 & 32 & 38 & 37 & $36 i$ \\
\hline "srown" & $5 s$ & 32 & 31 & 24 & 25 & 13 \\
\hline $\begin{array}{l}\text { vo differnuce } \\
\text { and over }\end{array}$ & 21 & 39 & 37 & 38 & 3.8 & 51 \\
\hline White & 30 & 2.3 & 28 & 23 & 37 & $\mathrm{x}$ \\
\hline smown $\ldots$ & 45 & 43 & 35 & $2 f$ & 24 & $\mathrm{x}$ \\
\hline Vo difference $\quad . .$. & 25 & 34 & 37 & 51 & 39 & $x$ \\
\hline
\end{tabular}

*Tuls percentage pertains to the number of homemakers responding to the quostion. re. Whore the $\mathrm{X}$ s oecur lisere whre too few to have any significance.

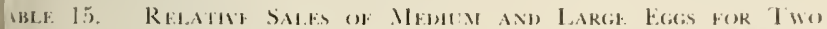

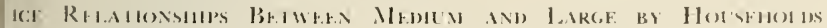

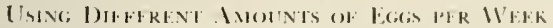

\begin{tabular}{|c|c|c|c|c|c|c|c|c|}
\hline \multirow{3}{*}{ 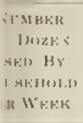 } & \multicolumn{4}{|c|}{ 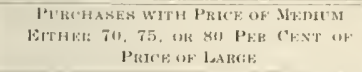 } & \multicolumn{4}{|c|}{ 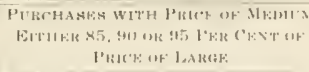 } \\
\hline & \multicolumn{2}{|c|}{ MF:MI } & \multicolumn{2}{|c|}{ DABtiE } & \multicolumn{2}{|c|}{ M калы M } & \multicolumn{2}{|c|}{ LAME: } \\
\hline & IMJE: & $\%$ & I117KN & $\%$ & Dazwas & $\%$ & 1)\%кN & $\because$ \\
\hline & 194 & 50.4 & $194 i$ & 49.6 & 212 & +3.4 & 276 & . iti.fi \\
\hline & 565 & 52.0 & $52: 2$ & 45.0 & 501 & 43.3 & $6 i 5 \mathrm{ti}$ & $5: 1: 7$ \\
\hline & 319 & 63.8 & $1 \times 1$ & 35.2 & 297 & ix.s & 311 & .11 .2 \\
\hline & 154 & 58.8 & 1118 & 41.2 & $10 \mathrm{~s}$ & 14.8 & $1: \because$ & $5 \pi .2$ \\
\hline & 164 & 80.1 & 411 & 19.6 & $5 ?$ & 50,4 & กד & $1 !+1$ \\
\hline rotal & 1401 & 57.2 & 1047 & +2.8 & 1177 & 45.1 & $14: 3: 3$ & $5.4,4$ \\
\hline
\end{tabular}




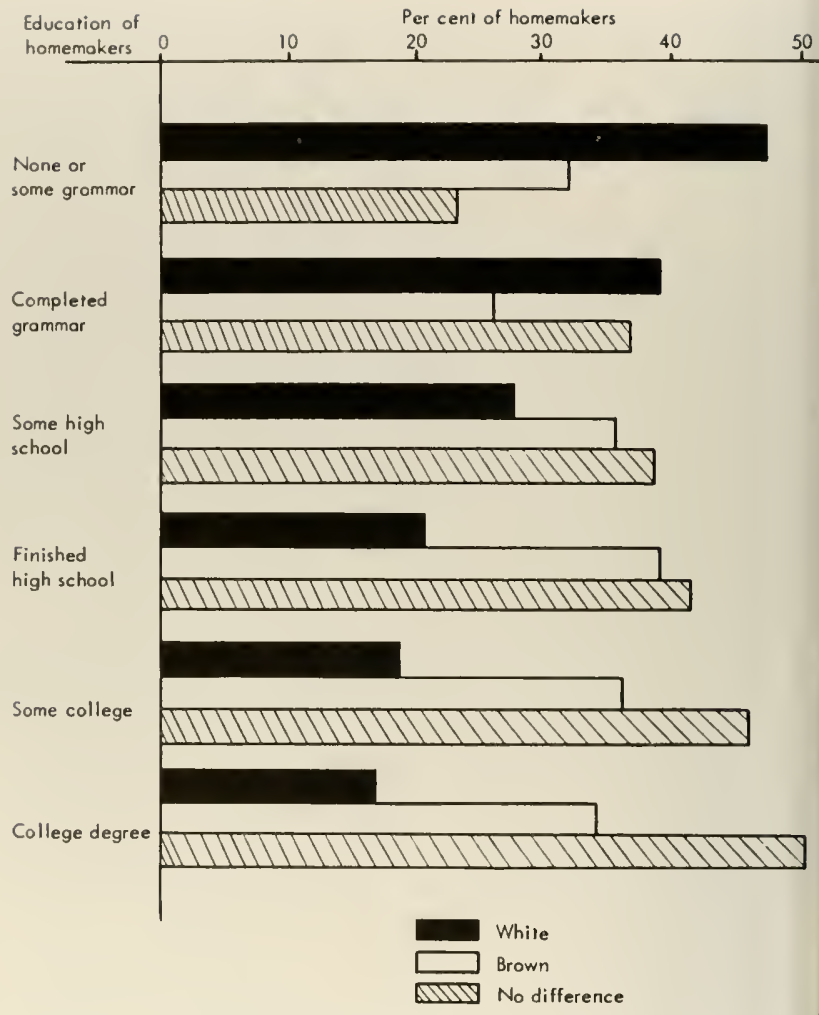

FIGURE 5. Preferences for shell color of eggs stated by homemakers $w$ different amounts of formal education.

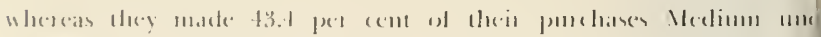

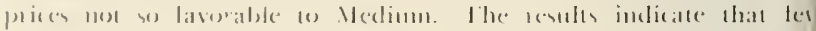

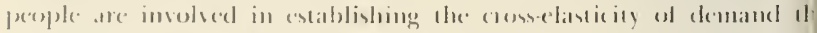

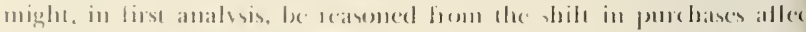

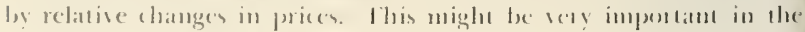

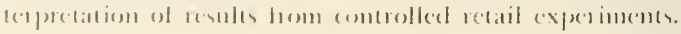




\section{remiums for Egg Quality Affected by Beliefs of Consumers}

In the State-wide surve on egg preferences the respondents were aked how much more they were willing to pay Ior Gracle A than for irade B eggs. Eighty-two per cent of the homemakers were willing to ay some price preminm for Grade $\lambda$. The average difference homelakers were willing to pay was 1.18 cents per cloren (see Table 16).

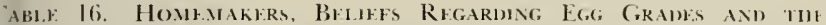
MUN'T OF PREMIUM THEY WOILI PAY FOR A DOZIN GRAIF I Eggs OVER a DothN GRade B Eggs

\begin{tabular}{|c|c|c|c|}
\hline \multirow{2}{*}{$\begin{array}{c}\text { BELEFS IN THE } \\
\text { IFFRRENCE BETWFEN } \\
\text { GRADE A AND } \\
\text { GRADE B }\end{array}$} & \multicolumn{2}{|c|}{$\begin{array}{l}\text { HOMEMAKERS } \\
\text { HOLDNG THE } \\
\text { VIEW EXPRESAED } \\
\text { IN FIRST COLUMN }\end{array}$} & \multirow{2}{*}{$\begin{array}{l}\text { Averagf Number of Centa Premitum } \\
\text { Grofp is Willing to Pay Per Dozhin } \\
\text { ror Grade A Over Grade B Eligs }\end{array}$} \\
\hline & NUMRER & $\begin{array}{l}\text { PER CENT } \\
\text { OF TOTAL }\end{array}$ & \\
\hline $\begin{array}{l}\text { difference in quality } \\
\text { ween Grade A and }\end{array}$ & & & \\
\hline ade is is a difference & 1,258 & 28.2 & 2.85 \\
\hline $\begin{array}{l}\text { the quality } \\
\text { ade } A \text { fresher. } \\
\text { aner, or better }\end{array}$ & 3,185 & 69.7 & 5. 16 \\
\hline vor $\ldots \ldots \ldots \ldots$ & 1,388 & 30.4 & 5.60 \\
\hline $\begin{array}{l}\text { ade } A \text { are larger } \\
\text { ade } A \text { stands up }\end{array}$ & 502 & 11.0 & 4.84 \\
\hline tere food value in & 113 & 2.5 & 5.87 \\
\hline $\begin{array}{l}\text { gde A .......................... } \\
\text { n't know what }\end{array}$ & 15 & .3 & 4.73 \\
\hline $\begin{array}{l}\text { difference is ........ } \\
n^{\prime} t \text { know whether }\end{array}$ & $1,1 \mathrm{fiT}$ & 225.5 & 4.72 \\
\hline re is a difference .. & 97 & 2.1 & 3.59 \\
\hline Total ,..................... & $4,5711 *$ & 100,0 & +.48 \\
\hline
\end{tabular}

- The total is made of the three italir-face numbers, Note that there are five subsses of those who believe there $i$ is a difference in quality.

All honemakers are not, ol course, willing to pay the same amomnt pemium. With complete inlomations on the homemakes it womld logeral that the diflerence in amount, if the amount is a rational e, wonlal be assu ialled with some comdition on amditims. Hhere were

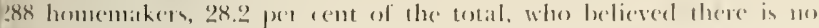

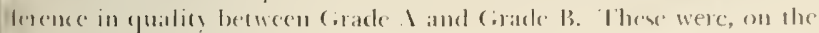

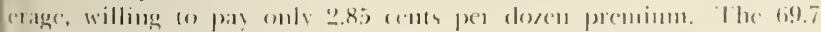

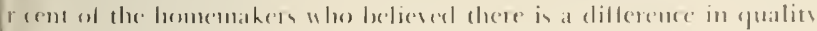
re willing to paly an asrage of 5.16 rens por dosen preminm for

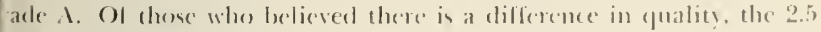

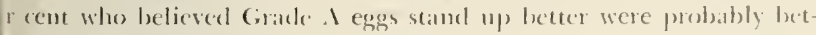
infommed than were the other gumps at least thin evidenced the incipal manifest differenc between the two egg grates. 'This group) 


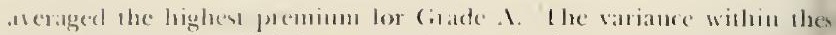

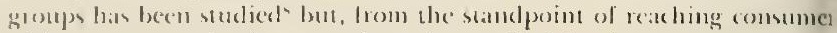
with posper monivations, needs to be smolied further.

\section{Weight-basis vs. Dozen-basis of Pricing Eggs}

several weight-basis experinents have been run in W'est Virgini. One of these, designed to study not only preference but also the acce tance trend was run lon a period of 10 months. In this study weigh

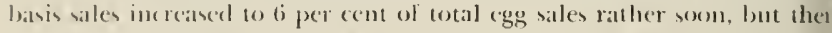
the trend leveled oll. In this experiment it was necessary for the cu tonser to select rggs and go to the meat counter to have them weigher

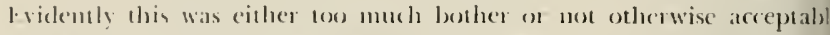
(0) omtomers. Ober weight-basis experiments in which total dozens wet weighed and priced belore the were put in the display rase showe a high enstomer are eptance. The retailes objected somewhat to custom handling and disturbing of eggs in the display. It is doubleful, once tl customers have become accustomed to this method that they would di tulb a displat of this type ol ollering more than they would one of weigh classed eggs sold by the dorent.

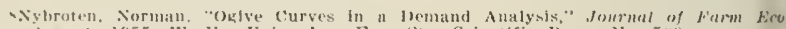

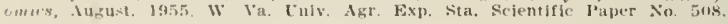

